\title{
Exploring the Power Dynamics within an EMI Content Based Course in Japan: A Case Study
}

\author{
Keith C. Hoy \\ Hiroshima Shudo University, Japan
}

\begin{abstract}
In many English as a Medium of Instruction (EMI) content-based university courses in Japan, there are power dynamics in play with high-status individuals, namely native language speakers (L1) and proficient second language speakers (L2) at the top, and Japanese L2 speakers at the bottom. The question is: how do we achieve a more egalitarian and participatory environment in which a low-status speaker feels not only less intimidated by other L2 interlocutors, but also less constrained by native speaking (NS) norms and values? To answer this question, this paper will examine a case study of an EMI course offered at a private university in Hiroshima. In particular, it will focus on the pedagogic strategies and practices the instructor at this university used to create a Community of Practice $(C O P)$ in which mutual engagement, joint negotiations and shared experiences and expertise were goals which all members could achieve. There were 18 participants in this case study: 11 Japanese, 4 L1 speakers (2 Americans and 2 New Zealanders) and 1 Chinese, French and South Korean. Data collection was based on the participant's quantitative and qualitative feedback of their performance in their group discussions. Additional analysis came from informal interviews from the students as well as personal insights from the instructor. These results revealed that although power still rested with the NS students, there was evidence that accommodations were being practiced by all participants thus creating a more harmonious COP. Lastly, a brief follow-up to this case study will be examined.
\end{abstract}

\section{Introduction}

It goes without saying that Native Speaker's (NSs) of English quite often modify discourse features of their speech to enhance comprehensibility when interacting with Non-Native Speaker's (NNSs) of English [17]. In addition, Ellis [5] argued that the NSs' goal is to "negotiate meaning," eluding conversational trouble and repairing trouble when it does arise. The question is: do these things naturally occur when you combine NSs with NNSs in an academic classroom environment in which their opinions -within a group setting- need to be shared and explained? The best approach to examine this issue is based on a poststructuralist, or process- oriented view of how second language learners (L2) are socialized into academic discourse. Basically, this looks at L2 learners' socialization through primarily oral activities such as discussions and presentations [9], [12], and that this process is open, conflictual, and dynamic rather than autonomous, coherent, or static [15]. Central to this poststructuralist view is the concept of a Community of Practice or (COP) [10]. The basic tenants of a COP are as follows:

...Learning is a socially situated process by which newcomers (namely L2 learners) gradually move toward fuller participation in a given community's activities by interacting with more experienced community members or NSs - a process called legitimate peripheral participation (LPP). Fuller participation means becoming increasingly competent in academic ways of knowing, speaking, and writing as they participate peripherally and legitimately in academic practices [13].

According to Wenger [18], peripherality and legitimacy are necessary to make newcomers' actual participation possible. Peripherality means "an opening, a way of gaining access to sources for understanding through growing involvement" [11]. It should also be noted that individuals can belong not just at the core or the margins of a COP, but that individuals' positions within a COP can change over time. Lastly, in order to be on an inbound trajectory, newcomers must be granted enough legitimacy to be treated (usually by the NSs or those with a high-level of English skills) as potential members.

For many NNSs -even those with a very high-level of English proficiency- engaging with NSs within a COP setting causes a lot of fear, social discomfort, embarrassment and misunderstanding. As a result, a hierarchical status of a group is formed in which a particular group member is viewed as an expert or an authority (be it in the language and or content). It goes without saying that a power imbalance within the group can be readily observed in which the dominant or high-status speakers tend to speak the most while the low-status speakers speak the least. The penalty resulting from such hierarchies is that low-status speakers may have marvelous ideas, but never have the chance to verbally express them [7]. Many studies have been cited describing East Asian international students as having difficulty in taking active roles in class discussions because of their insufficient English skills or different cultural backgrounds [2], [3], [6], 
[9], [12], [16]. Many of these students have little experience being socialized into a western, or more specifically a North American style of classroom practices. The studies by Morita [12] and Hyung [9] demonstrate how difficult it was for East Asian graduate students to gain legitimacy within their COP even though they met the standard Test of English as a Foreign Language (TOEFL) levels for entry. In addition, these two studies revealed that both native and international students seemed to acknowledge the fact that there was a power imbalance distributed amongst graduate students depending on the "nativeness" of their English. Those who could speak more in classroom discussions gained more access to power and those who could not often felt marginalized. Marginalization in this context meant a lack of oral participation (ie asking questions or giving opinions) be it in a group setting or the class in general.

Lastly, given that a power imbalance exists in this kind of COP, is there any information in the literature that reveals clues to rectifying this problem. According to the study by Hyung [9] both the NS and NNS participants felt that some sort of accommodation can be accomplished by adjusting the speech rate (ie slowing the pace of the NSs speech) as well as refraining from, or at least explaining idioms unfamiliar to international students. Along the same lines, Morita [12] goes further by having professors, and or NS students provide cultural or background information (when necessary) that international students may not be familiar with. In addition, NS students and the professors teaching the course should take into account that there is a time lag in terms of having a NNS process the information, and then later talking about it. Giving a moment of extended time here is important because it legitimizes a NNSs importance within their COP. A vibrant COP is one in which all learners, L2 as well as native speaking students value each other's unique intellectual and cultural contributions. Finally, some other pedagogical interventions -especially at the instructor's end-include: explaining the purposes of a discussion, summarizing the discussion from time to time, intervening to allow more marginalized students take part in the discussion, encouraging all students to achieve participation in a collaborative and egalitarian manner, designing discussion topics that incorporate the international students' perspectives as legitimate sources of knowledge, presenting in class to ensure that NNSs can practice both the linguistic and cultural aspects of oral academic discourse and employing different types of classroom activities that encourages students with various needs or interactional styles to participate [12].

\section{Background}

This course was entitled "Advanced English (Contemporary Issues in Japanese Society)". It was a 16-week course taught in English and was offered in Term 1 (April-July) of 2016. The course was open to Japanese students of this particular university who were in years 2-4 of their specific undergraduate program. The other stipulation for entry was a Test of English for International Communication (TOEIC) score of 500 and above. Based on these requirements, 11 Japanese students enrolled in this class of which only 1 dropped-out after attending the first 5 classes. The reason this student dropped-out could not be determined but based on observations from the instructor it seemed as though this student had a difficult time keeping up with the course content and classroom discussions. Incidentally, this student had a TOEIC score of 525 which placed him with 5 other students who were in the 500-599 range. As for the other Japanese students, 2 were in the 600-699 range, while 1 each was in the 700-799, 800-899 and 900990 ranges respectively.

As for the international students, 7 of them were enrolled in undergraduate programs at universities in their home countries. The breakdown of their countries was: America (2), New Zealand (2), France (1), South Korea (1) and China (1). There were 4 native English speakers from this group of 7 students ( 2 from America and New Zealand). As for the other 3 members, the participant from France received a perfect score of 990 on her TOEIC while the participants from South Korea and China could not recall of having taken any standardized English proficiency tests. Given that these 2 non-native speakers of English did not have any standardized record would seem problematic, however in the first class it was obvious to the instructor that these 2 students had the necessary speaking, listening and writing skills to participate in all facets of the course content (i.e. near native fluency). Out of these 7 international students, 3 of them dropped-out (1 from America, France and South Korea) in the first 5 weeks of the course. Based on the information that was gathered from staff and other faculty members, the reason for them dropping out was that they, or more specifically the universities that they belonged to in their home countries, did not recognize this course for credit.

\section{Course Content}

The content of this course focused on contemporary issues in Japanese society. The book that best incorporated this content along with idea of tapping into and guiding the opinions and knowledge of second language learners (particularly Japanese) was: "Hot Topics Japan 2". This book was chosen for 2 reasons. First, the vocabulary, listening, reading and 
speaking activities were geared towards those students at the intermediate to the advanced level (i.e. a TOEIC score of 500 and above). Second, the book provided enough interesting and novel material for both international and Japanese students to do further research.

The book is divided into 5 areas of study: People and Society, Health and Fitness, Children and Education, Science and Technology and Art and Culture (refer to Figure 1-Topics examined during the course). Since there were more units than could be covered in a 16-week course, only 2 out of the 3 units from each area of study were done in class. The contents from each unit were also supplemented with short lectures, video clips and handouts in the form of newspaper articles and worksheet exercises. The last 3 weeks of the course were devoted to studentgenerated research and discussion on a contemporary based topic that they were interested in. Based on Figure 1, the instructor highlighted some other topics to consider which could be explored in greater detail if the student decided to do so. In many instances the topics that they would research for their final discussion overlapped into 2 areas of study. For example, the topic "Suicide rate in Japan", overlapped both the areas of People and Society and Health and Fitness.

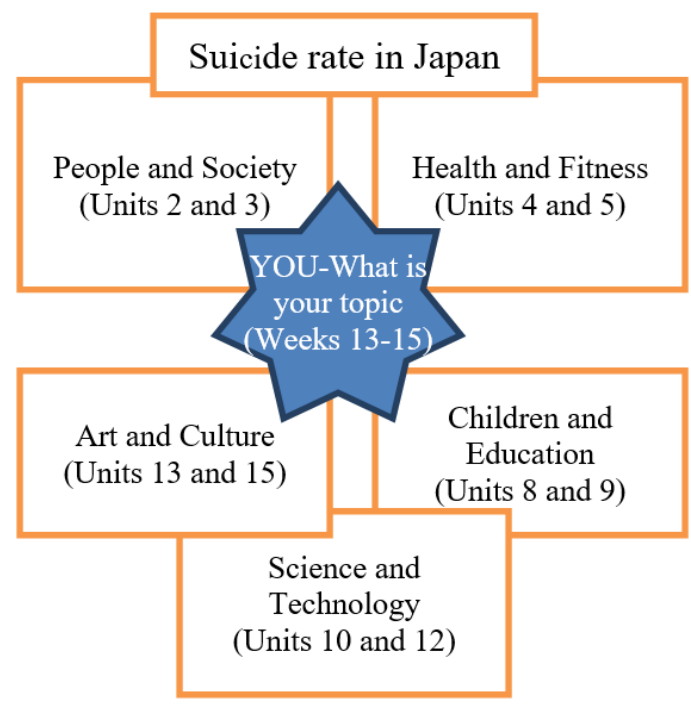

Other topics to consider...

- Declining birthrate in Japan

- Suicide rate in Japan

- Territorial disputes (China, Korea etc..)

- Your own

Figure 1. Topics examined during the course

The layout of each unit in the book "Hot Topics Japan 2", followed a Content and Language Integrated (CLIL) approach which clearly gave the student the necessary vocabulary, listening and reading comprehension skills before engaging in any in-depth style discussions. For example, each unit began with a focus of the target vocabulary being used. This was accomplished through a series of short vocabulary preview and practice exercises. After that, students moved to a content focused listening activity which was presented as a short talk or conversation. It was here that the students listened and took notes according to a knowledge map. Next, the reading comprehension section integrated what the student had learned in the previous activities and organized this information into a concept diagram. The concept diagram had missing information that the student had to find within the reading. All these exercises prepared the student to take part in a series of openended discussion questions which were sometimes done in pairs or groups. Finally, there was an assignment section which could be done in-class or for homework. This section usually involved the student reflecting on some personal experience or opinion about the unit being studied. This required that the student take notes and present their views to a group of their fellow classmates. There were several occasions in this course where they had to do this.

\section{Assessing progress}

While it was important for students to learn and synthesize the content they received in class, it was equally vital for them to communicate their ideas effectively within a group setting. In other words, they had to practice and develop the kind of language that best conveyed certain ideas as well as how to use this language in the social dynamics of a group setting that they would be interacting in. In order to accomplish this, on the first day of class the instructor handed out a 7-page document entitled, "Key Phrases used for discussing Contemporary Topics" (see Appendix 1). This document was given to all the students (both Japanese and international students) with the intention of getting them to practice these phrases as early and as much as possible. Even for the native speakers of English, this document was important because they would be excellent role models as to when and in what situations to use this language. Besides the key phrases document, students also had to learn the principles of how to communicate their ideas within the context of a group. Therefore, another handout entitled, "5 Keys to Effective Communications within a Group" was also distributed on the first day of class (see Appendix 2). The intention of this handout was to have students understand and practice the 5 skills necessary (ie Confidence, Assertive, Initiative, Logic and Openmindedness) in order to interact successfully when it came to group discussions.

The best way to monitor student progress as it related to the information in Appendix 1 and 2 was to give students a 10-point rating scale in 4 skill areas. 
These 4 skill areas were: Leadership (Taking Initiative), Communication, Interpersonal, and Problem-solving and Conceptualizing (see Handout 1- Rubric for Evaluating Progress in the 3 Discussions). In terms of Leadership (Taking Initiative) skills, students needed to be aware of how they performed in areas related to initiating or directing a conversation, intervening when necessary and encouraging other members to speak. In terms of Communication skills, attention focused on using simple and precise language, speaking fluently and substantiating points through proper reasoning (refer to the key phrases in Appendix 1). As for Interpersonal skills, emphasis was placed on areas such as considering other points of view, being a good listener and having a positive attitude. Lastly under Problem-solving and Conceptualizing skills, students needed to assimilate information raised by others, speak spontaneously and analyze situations from different perspectives.

In addition to Handout 1, students also had to fill out a more detailed critique regarding their participation in the discussion sessions. Specifically, they had answer 3 questions: 1.) Was there anything that they did particularly well in; 2.) Was there anything that they found challenging; 3 .) What would they do differently next time to improve the quality of their inter-actions within the group (see Handout 2Self-reflection Sheet based on Discussion). In terms of providing more in-depth answers to questions 1,2 and even 3 , students referred to the 10-point grading rubric in Handout 1. Lastly question 4 of Handout 2 (on scale of $0-10$, how would you rate your performance for this discussion?), required that the students reflect upon the comments that they made in questions 1-3 as well as the graded rating scales for the 4 skill areas of Handout 1.

Handouts 1 and 2 were distributed after every major group discussion ( 3 in total). The assessment periods were carried out in weeks 3,8 and 13-15. The 1 st and 2nd assessments were based on questions from a specific unit being studied in the "Hot Topics Japan 2 " text. These 3-4 questions usually had the student reflect on some personal experience or opinion. Students had one week to prepare, and these two assessments were worth $25 \%$ each. The $3 \mathrm{rd}$ and last major discussion was worth $50 \%$ of their discussionassignment mark. It was this last major assignment in which students had 3 weeks to research, discuss and lead their own topic or article on a contemporarybased theme that they were interested in. In addition, the research consisted of students handing in the following written information: the source(s) that the student got the information from, a summary of the article and why they chose this article. Lastly, each discussion leader had to come up with 3-5 questions to ask their group. Their group members also received the same article to read and review prior to the session. Students also had the option to present their article from a Japanese source(s) as long as the written information and the discussion was conducted in English. Incidentally, the instructor made sure that the discussion groups for each assessment remain diverse in that it contained at least $1 \mathrm{NS}, 1$ high-level L2 speaker and an equal number of 2 nd, 3 rd and 4 th year students as well as males and females. Finally, these discussion sessions were not only judged according to the student's performance in the discussions (as shown in the rating scales of Handouts 1 and 2), but the preparation that they had to do for it (ie notes that they prepared for their discussion and the quality of their self-assessments).

\section{Findings based on the assessment rubrics}

The following information examines some of the major results that came out of the assessment rubrics of Handouts 1 and 2. It focuses on 4 areas: language ability, background knowledge and interest in contemporary issues, the weakness and strength of the student's language abilities and the assessments made by the students and the instructor. First in terms of language ability, those Japanese students with higher TOEIC scores tended to fair better than those who had lower scores (particularly those who just met the minimum entry score of 500). For example, the higher the TOEIC score, the easier and faster it was for these students to do the listening and reading comprehension sections of the book. Again, it should be noted that the book was intended for Japanese students at the intermediate to the advanced level and according to the instructor and the students, the content and the exercises in the book were ideally suited for this class. The one area that highlighted the differences between those with higher versus lower TOEIC scores was when the Japanese students had to enter into the discussion phase with the international students. In this case, only 2 out of the 11 Japanese students in this class were able to really engage in all 4 skills areas (see Handout 1) with the international students. Upon closer examination, these two students had a TOEIC score of 920 and 810 respectively. A special note also goes out to one student who posted a score of 700 and although he wasn't as communicative as his higher-leveled peers, he managed to keep up with the international students in the group conversations. Not too surprisingly all 3 of these students were English majors.

\section{Handout 1 - Rubric for Evaluating Progress in the 3 Discussions}

Name:

You will develop and be assessed on these following skills throughout our discussion sessions. 


\section{1) Leadership (taking initiative) skills}

- Initiate the group discussion and give proper directions to the discussion.

- Intervene and guide the group when the discussion goes off track.

- Encouraging all members to participate in the discussion \& share their opinion.

- Moderate group if discussion gets off topic or becomes chaotic

0----1----2----3----4-----5----6----7----8-----9----10

\section{2) Communication skills}

- Hold the attention of the group by using simple language.

- Explain ideas in precise way with clarity (see handout on key phrases from Appendix 1)

- Speak fluently and put forward ideas without hesitation.

- Be expected to substantiate the points you raise through proper reasoning.

0----1----2----3----4----5----6----7----8----9----10

\section{3) Interpersonal skills}

- One should consider other members viewpoints (if it is a valid one) and should not be pushing too hard to make his/her own point.

- $\quad$ Try to coordinate as much as possible with all group members

- If a group member raises an absurd or irrelevant point it should be politely rejected by giving proper reasoning.

- Be positive, don't take things personally

- Be a good listener when others are speaking

0----1----2----3----4-----5----6----7----8----9----10

\section{4) Problem-solving and conceptualizing skills}

- Assimilate (summarize) the points raised by others and try to add something new to the discussion.

- $\quad$ Should be able to think and speak spontaneously

- Analyze the situations from different angles/perspectives

0----1----2----3----4-----5----6----7----8----9----10

\section{Handout 2 - Self-reflection Sheet based on Discussion}

Please refer to the rubric in Handout 1 to help you in your reflection.

1) Was there anything about this discussion that you felt you did particularly well in. Please provide examples by referring to the rubric in Handout 1.

2) Was there anything about this discussion that was particularly challenging (or difficult). Please provide examples by referring to the rubric in Handout 1.

3) What would you do differently in your next discussion that would improve the quality of your interactions within your group (i.e. any improvements you could make).

4) On a scale of 0-10, how would you rate your performance for this discussion?

$$
\text { 0----1----2-----3----4-----5----6----7-----8----9----10 }
$$

Assessment handout supplied to all students on April $26^{\text {th }} 2016$

As for the other pupils -and it didn't really matter what major they were in -it was the experience of conversing with the international students which proved most difficult. In fact, 2 students had a profoundly difficult time in the discussion phase and told me so in their written self-evaluations (ie a lack 
of vocabulary and confidence speaking in front of others). In general, a majority of the Japanese students expressed that the issue wasn't so much the level of the content as it was with the pace and the everchanging subject matter within the content. Based on the observations of the classroom instructor, a large number of the Japanese students tended to be quiet during the discussion phase. "Quiet" in this sense meant recognizing that the power dynamics belonged to students who had better English skills (i.e. those with higher TOEIC scores, as well as those who are native or near-native speakers of English).

Another area concerns background knowledge and interest in contemporary issues. From the perspective of the classroom teacher, his Japanese students did not have as much knowledge about the contemporary issues facing their own country as he thought they did. This information was reaffirmed from one of the international students when she wrote in her personal biography:

...I wonder why Japanese university students are not concerned so much about world affairs-human rights. One time, a Japanese student asked me what I was reading, and I told her it was an article about gender equality and she said, oh that's boring... (Student personal biography-April 19, 2016).

$\mathrm{Be}$ that as it may, those students who either travelled overseas, or who were a little older, seemed to have more knowledge about contemporary affairs than those who didn't (ie they could draw upon more of their life experiences). For example, at least 4 of the Japanese students who contributed the most during the discussion phase were 3rd and 4th year students. There was also one 2nd year student who travelled extensively while growing up. He was able contribute at times to the conversation with his own unique observations and perspectives

Based on the data from the student selfassessments, some language learning characteristics were raised which revealed both weak and strong points with these Japanese students. First, the weak point that all the Japanese students seemed to have difficulty with -not too surprisingly- focused on the 4th skill area of Handout 1 which was problemsolving and conceptualizing skills. As one student stated in her self-reflection: “...It's always challenging for me for me to organize things that I would like to speak out in my mind" (Student selfevaluation-April 26, 2016). Another student mentioned: "It was difficult for me to understand what others said and think about the topic at the same time..." (Student self-evaluation-April 26, 2016).

Obviously being able to solve problems and conceptualize was not a major issue for the native speakers. All of them used these skills to varying degrees. There was one international student however, who was very good at both repeating and stressing the right vocabulary and phrases as it related to this skill. In other words, this person was an excellent role- model because he helped the Japanese speakers hear, see and understand the importance of using this skill within a discussion. The instructor also stressed to the native speakers at the beginning of the course that engaging in problem-solving and conceptualizing skills are important, but it cannot work without incorporating the 3 other areas of the discussion rubric (Leadership, Communication and Interpersonal skills). The result was that if the student (regardless of being Japanese or International) incorporated all facets of the rubric, it would encourage others in their respective discussion groups to speak up more.

As far as strength is concerned, the one area that all the Japanese students did consistently well in was the 3rd skill area of Handout 1 which was Interpersonal skills. Specifically, the Japanese students demonstrated progress at showing good listening and positive attitudes. For example, the comments that was mentioned by one student summed up how many of the Japanese students felt when they compared their first discussion session with their 2nd and 3rd discussions: “...Maybe I think I tried and worked the best. I could even more listening carefully and actively when other classmate speaking" (Student self-evaluation-May 24, 2016). Another student made a point of frequently using words like: "ah-ha" or "right" and "that's nice" in her subsequent discussions. At the same time, it should be noted from the teacher's perspective that the consistent and increased use of these skills could also be interpreted as students really needing to concentrate harder than their higher-skilled peers for fear of missing important information. As one student commented: "Last time I was very nervous and couldn't understand what members speak. This time I was very nervous, but I could smile and ask some question to members." (Student self-evaluation-May 24, 2016). Based on the in-class observations of the discussions, those students who couldn't contribute as much in terms of leadership, communication and problem-solving skills certainly made up for it in their interpersonal skills.

Finally, based on the self-assessments of Handouts 1 and 2, those Japanese students who had lower language abilities due to their TOEIC entry scores) gave themselves overall ratings ranging from 1 to 3 on the 10-point rating scale in question 4 of Handout 2 (see Figure 2. Discussion Self-Assessments of Japanese Participants). Specifically, these lower selfassessment scores came from Students 1 to 5 and was clearly evident in their first discussion session. Although these ratings were lower than what the instructor would have given them, it wasn't until their subsequent sessions ( 2 and 3 ) that these same students assigned themselves scores which were more in line with the teacher's ratings (ie scores of 5 or 6 ). Of course, they also made legitimate improvements which was reflected in their higher ratings. Not too surprisingly, the top 4 Japanese students (Students 7 , 
8, 9 and 10) gave themselves scores ranging from 6-9 and that these ratings were fairly consistent throughout all 3 of their discussion sessions.

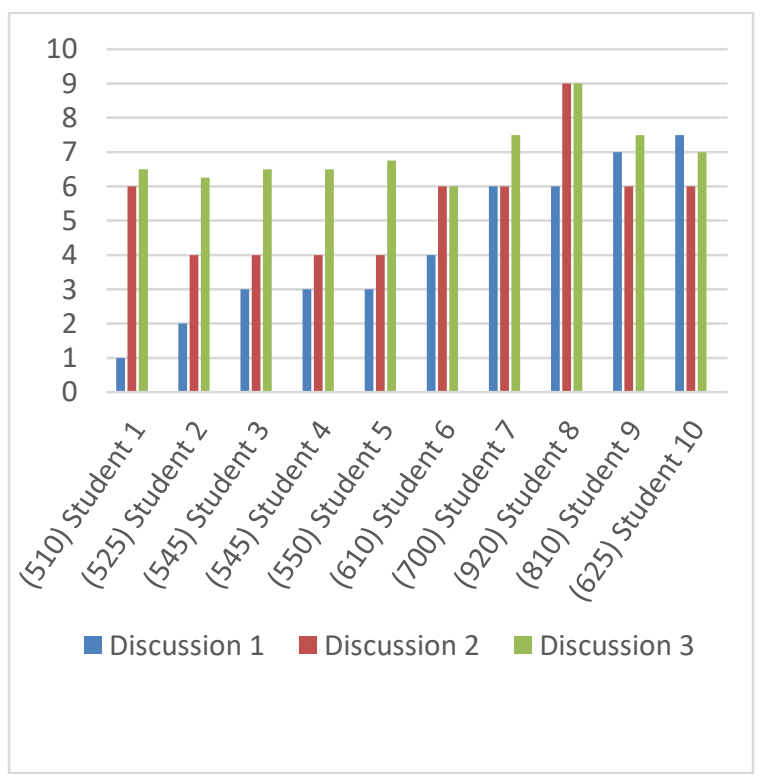

Figure 2. Discussion Assessments of Japanese Participants

Another area of assessment looked at the final mark distribution (60\% discussion-assignment; $20 \%$ participation; $10 \%$ quizzes and $10 \%$ final test) in which the Japanese students did fairly well considering that their discussion grades weren't as high as the international students. Based on their 3 major discussion sessions the Japanese students prepared very well for their final discussions. They found the articles that they wanted to talk about and their note preparation was just as detailed as the international students. As mentioned previously, there was an option for the Japanese students to present their article from a Japanese-language source or sources, but none of them took up this offer. In terms of their participation grade (worth 20\%), the Japanese students did well as long as they attended all their classes -which most of them did. Next, in terms of the quizzes and the final test, it was based on content presented from the course book. Questions were mainly in the form of matching and short answers. Surprisingly the international student's final exam grades weren't any higher than the Japanese students.

\section{Conclusion}

Based on the results of the data, one can clearly see that the COP in this class contained some similarities as well as differences when compared to the characteristics of the COP in other studies [9], [12]. In terms of similarities, the hierarchy of power in this class rested with those who had the greatest proficiency in English: specifically, the NSs. Right from the start of the discussion sessions the NS students ( 2 from New Zealand and 2 from America) asserted their dominance. Of course, at the same time, the majority of NNSs accepted the fact that this was an asymmetrical relationship which resulted in the NSs-and to a lesser extent the near native speakersseizing the majority of speaking turns. As far as feelings of marginalization, many of the NNSs (mainly Japanese) expressed a variety of views which were consistent with international students in similar settings. In particular, the one area that all the Japanese students had the most difficulty with was using problem-solving and conceptualizing skills. In other words, it was extremely difficult for these students to summarize and speak spontaneously about points that come up in any of the discussions.

As far as differences were concerned, there was a concentrated effort by the instructor to legitimize any learner who would feel marginalized by providing a sheet of key phrases for them to use when discussing contemporary topics (see Appendix 1) as well as a sheet on how to communicate effectively within groups (see Appendix 2). Actually, these two sheets were distributed to all the members in the class with a special emphasis on paraphrasing and summarizing any information to ensure understanding at all levels. Lastly, there were times throughout the course that the instructor relied on the NSs to support the NNSs in terms of clarifying or explaining unknown vocabulary, phrases or idioms. This situation worked out very well as the NNSs appreciated the help and at the same the NSs did not feel any unusual burden in offering them this support. By doing these things the instructor realized that he was legitimizing the peripherality of the NNS, but considering that these Japanese students came with considerably lower levels of English skills than those who would attend graduate schools in North America, this was to be expected. In addition, the book that was chosen for this course was at a suitable level for these L2 students. For example, it provided content through a series of guided vocabulary, listening and reading activities which culminated in discussion activities which tapped into the personal experiences and knowledge of most Japanese students. Naturally this book was too easy for the NS, so this was supplemented with optional readings which were geared towards those whose first language was English. Finally, considering that the NS students were studying Japanese language and culture at this university, they also relied on the Japanese students in this class for unknown vocabulary or phrases that occasionally came up in the book or during the discussions. For the most part, there was an attempt to level the playing field which opened the path for a more egalitarian style of COP. Albeit most of the power and control was still in the hands of the NS students, there was clear evidence that after each 
discussion session, the NNSs were slowly navigating their way into the core of their respective COP groups. Clearly if the opportunity came that would allow this course to carry on for a full year, these L2 students would benefit simply because they would be more competent in dealing with the linguistic and cultural aspects of oral academic discourse.

\section{Case Study follow-up}

In June of 2017, the EMI course "Advanced English (Contemporary Issues in Japanese Society)", was once again offered to the students of this university. Although the course content, textbook, teaching methodology and assessments remained the same, there were a few differences in terms of how the course was administered as well as the make-up of the class itself. On the other hand, the results of the students' self-assessments (see handouts 1 and 2) were different in terms of how the COP in this class was more harmonious than last year due to the different power dynamics that were in-play amongst this smaller class of higher-leveled students.

In terms of course administration and classroom make-up, there were some notable changes compared to the 2016 course. For example, the course ran 2 times per week over an 8-week period (June-July). The reason for the shorter and more intensive duration was due to timetabling issues for those Japanese students who wanted to study overseas. As far as the students who registered into the class, there were only 4: 3 Japanese females and 1 Korean male. The 3 Japanese were 4th year English majors and the Korean was a graduate level student taking undergraduate level Japanese courses at this university. In addition, all 4 students had TOEIC scores in the 800-899 range. Lastly, the 3 Japanese female students spent time (ranging from 7 months to a year) either studying English or doing internship work using English overseas. As for the Korean student, his only overseas experience has been in Japan because that is where he is currently doing his university studies.

The power dynamics displayed in this particular class revealed data suggesting that a greater degree of rapport and understanding was established in their COP, and that this was largely due to a number of factors. First, all the students were NNSs with roughly the same degree of English ability (as demonstrated in their TOEIC scores). Since there were no NSs in this class other than the instructor, it freed up the students' inhibitions in terms of having to conform to NS speaking norms and values. For example, in the 3 discussion assessments (lessons 3, 8 and 16) the instructor noted that although all 4 students made plenty of mistakes in terms of grammar and word choice, the most important factor was their communicative intent. These students were more concerned about making sure that their message was understood and if wasn't, they would negotiate meaning through repetition or clarification. At times this clarification was done in Japanese. Based on the instructor's observations these 4 students had few, if any major problems engaging in all 4 skill areas of the self-assessment in Handout 1. Based on the preliminary results, these students gave themselves scores ranging from 6-9 on all 4 skill areas of the 10point rating scale and that these scores improved after each major discussion assessment. Incidentally, these ratings are consistent with the top 2 Japanese students from last year's course (see Figure 2. Discussion Assessments of Japanese Participants -students 8 and 9). If there were any difficulties that this group of students experienced, it would be the 4th skill area in Handout 1: Problem-solving and Conceptualizing Skills. Obviously, this skill is difficult for many speakers including NSs, but for the most part these 4 students made improvements in trying to summarize and be more spontaneous in their discussion sessions. Finally, the fact that there were only 4 students gave them plenty of time to practice and refine their group discussion skills related to the areas of negotiation of meaning and accommodation which in turn, created a COP that was clearly convivial and productive for all those involved.

\section{References}

[1] Alexander, S., Hot Topics Japan 2 A Culturally Specific Discussion Book. Compass Publishing, Tokyo, 2015.

[2] Chen, T., "Reticence in class and on-line: Two ESL students' experiences with communicative language teaching”. System, Pergamon, 31(2) 2003, pp. 259-281.

[3] Cheng, X., “Asian students' reticence revisited". System, Pergamon, 28(3) 2000, pp. 435-446.

[4] Cohen, E., Designing group work: Strategies for the heterogeneous classroom. Teachers College Press, New York, 1994.

[5] Ellis, R., Understanding second language acquisition. Oxford University Press, Oxford, 1986.

[6] Flowerdew, J., \& Miller, L., "On the notion of culture in L2 lectures”. TESOL Quarterly, 29(2) 1995, pp. 345-374.

[7] Freiermuth, M. R., "Native Speakers or Non-Native Speakers: Who Has the Floor? Online and Face-to-Face Interaction in Culturally Mixed Small Groups". Japan Computer Assisted Language Learning, 14(2) 2001, pp.169-199.

[8] Hayashi, R., Cognition, empathy and interaction: Floor management of English and Japanese conversation. Ablex Publishing, New Jersey, 1996.

[9] Hyung-Jo, Y., "Challenging the "non-native speaker" identity in the U.S. higher education: A case of international graduate students". Working Papers in Educational Linguistics, 28(2), 2013, pp. 55-75. 
[10] Lave, J., \& Wenger, E., Situated learning: Legitimate peripheral participation. Cambridge University Press, Cambridge, 1991.

[11] Leet-Pellegrini, H., "Conversational dominance as a function of gender and expertise". In H. Giles, W. Robinson \& P. Smith (Eds.), Language: Social Psychological Perspective, Pergamon, Oxford, 1980, pp. 97-104.

[12] Morita, N., "Negotiating participation and identity in second language academic community". TESOL Quarterly, 38(4) 2004, pp. 573-604.

[13] Miyazato, K., "Power-Sharing Between NS and NNS Teachers: Linguistically Powerful AETs vs. Culturally Powerful JTE's". JALT Journal, 31(1) 2009, pp. 35-62.

[14] Norton, B., "Non-participation, imagined communities and the language classroom." In M. P. Breen (Ed.), Learner contributions to language learning: New directions in research, Pearson Education, Essex, 2001, pp. 159-171.

[15] Prior, P. A., Writing/disciplinarity: A Sociohistoric account of literate activity in the academy. Lawrence Erlbaum and Associates, Mahwah, New Jersey, 1998.

[16] Tsui, A., (1996). "Reticence and anxiety in second language learning." In K. Bailey \& D. Nunan (Eds.), Voices from the language classroom, Cambridge University Press, Cambridge, 1996, pp. 145-167.

[17] Thonus, T., "How To Communicate Politely and Be a Tutor, Too: NS-NNS". Paper presented at the 20th Annual Conference of the American Association for Applied Linguistics, Seattle, 1998, March, 14-17.

[18] Wenger, E., (1998). Communities of practice: learning, meaning, and identity. New York:

Cambridge University Press.

Appendix 1.

\section{Key Phrases used for discussing Contemporary Topics}

\section{1) Giving and Asking for Opinions}

a) Giving Opinions

\begin{tabular}{|l|l|l|}
\hline Strong & Neutral & $\begin{array}{l}\text { With some } \\
\text { hesitation }\end{array}$ \\
\hline $\begin{array}{l}\text { I'm sure } \\
\text { that... }\end{array}$ & $\begin{array}{l}\text { I think/believe } \\
\text { that... }\end{array}$ & $\begin{array}{l}\text {-It seems to } \\
\text { me that... }\end{array}$ \\
\hline $\begin{array}{l}\text { I feel quite } \\
\text { sure that... }\end{array}$ & As I see it... & $\begin{array}{l}\text {-I'm } \\
\text { inclined to } \\
\text { think that... }\end{array}$ \\
\hline $\begin{array}{l}\text { I'm } \\
\text { convinced } \\
\text { that... }\end{array}$ & $\begin{array}{l}\text { From my point } \\
\text { of view... }\end{array}$ & $\begin{array}{l}\text { I tend to } \\
\text { favor the } \\
\text { view that... }\end{array}$ \\
\hline $\begin{array}{l}\text { I'm positive } \\
\text { that... }\end{array}$ & $\begin{array}{l}\text { The way I see it } \\
\text { is that... }\end{array}$ & $\begin{array}{l}\text { My } \\
\text { inclination } \\
\text { would be } \\
\text { to... }\end{array}$ \\
\hline
\end{tabular}

\begin{tabular}{|l|l|l|}
\hline $\begin{array}{l}\text { I strongly } \\
\text { believe that... }\end{array}$ & \\
\hline $\begin{array}{l}\text { I'm } \\
\text { (absolutely) }\end{array}$ & \\
certain that... & \\
\hline $\begin{array}{l}\text { It's perfectly } \\
\text { clear to me }\end{array}$ & \\
that... & \\
\hline $\begin{array}{l}\text { Without a } \\
\text { doubt... }\end{array}$ & \\
\hline
\end{tabular}

a.) Asking for Opinions

What do you think about...(*Name?)

What's your opinion about that (*Name?)

What's your reaction to that (*Name?)

What's your views on this, (*Name?)

(*Name), do you have anything to add?

Do you have any suggestions? (*Name?)

\section{2) Clarifying}

a) To ask for Repetition

I'm sorry, could you repeat that?

Could you go over that again, please?

Would you mind saying that again?

Could you say that (louder/more slowly?)

Sorry, I missed the first part. Could you say it again?

b) To ask for Clarification

\begin{tabular}{|l|l|}
\hline Notify & Clarify \\
\hline I didn't catch that. & $\begin{array}{l}\text { What exactly do you } \\
\text { mean by that? }\end{array}$ \\
\hline I don't follow you. & $\begin{array}{l}\text { Could you run through } \\
\text { that again }\end{array}$ \\
\hline I'm not with you. & $\begin{array}{l}\text { What exactly are you } \\
\text { driving at? }\end{array}$ \\
\hline $\begin{array}{l}\text { That wasn't totally } \\
\text { clear to me. }\end{array}$ & $\begin{array}{l}\text { Could you explain what } \\
\text { you mean? }\end{array}$ \\
\hline $\begin{array}{l}\text { I didn't quite catch } \\
\text { what you were } \\
\text { saying... }\end{array}$ & $\begin{array}{l}\text { Would you elaborate on } \\
\text { that? }\end{array}$ \\
\hline $\begin{array}{l}\text { I'm not exactly sure } \\
\text { what you mean. }\end{array}$ & $\begin{array}{l}\text { What are you trying to } \\
\text { say? }\end{array}$ \\
\hline $\begin{array}{l}\text { I don't quite see what } \\
\text { you mean. }\end{array}$ & $\begin{array}{l}\text { Could you be a little } \\
\text { more specific }\end{array}$ \\
\hline $\begin{array}{l}\text { I'm not sure I } \\
\text { understand you } \\
\text { correctly. }\end{array}$ & $\begin{array}{l}\text { Could you explain to me } \\
\text { (how/why?) }\end{array}$ \\
\hline
\end{tabular}

c) To confirm what the other person said, based on your understanding

\begin{tabular}{l|l}
\hline Re-stating & Confirming \\
\hline - Do you mean... & ・ Is that right? \\
- To paraphrase what & ・ Is that correct? \\
$\begin{array}{l}\text { you just said, you } \\
\text { stated... }\end{array}$ & • Have I got that right?
\end{tabular}




\begin{tabular}{|l|l|}
\hline - So, in other words,... & ・ Is that what you \\
- The point you are & meant? \\
trying to make is... & \\
- What you've just said & \\
is... & \\
- If I understand you & \\
correctly... & \\
- When you say...are you & \\
saying that...? & \\
- Let me see if I have & \\
that right. What you & \\
mean is... & \\
- So, what you're getting & \\
at is... & \\
\hline
\end{tabular}

d) To clarify yourself to the other person I said...

\section{Put simply...}

In other words...

What I'm saying is...

What I mean to say is...

What I'm trying to say is...

What I'm getting at is...

Let me clarify...

Let me say this another way...

To make a long story short...

e) To check whether the answer you gave to the other person was sufficient

...Is that okay?

...Does that make sense?

...Have I answered your question?

\section{3) Agreeing and Disagreeing}

a) Agreement

\begin{tabular}{|l|l|}
\hline Strong & Neutral \\
\hline Exactly/Absolutely & $\begin{array}{l}\text { I agree (with } \\
\text { you). }\end{array}$ \\
\hline Precisely/Definitely & You're right \\
\hline Yes, I know exactly what & $\begin{array}{l}\text { I think you're } \\
\text { correct. }\end{array}$ \\
\hline I'm in complete agreement. & $\begin{array}{l}\text { That's true/That's } \\
\text { right. }\end{array}$ \\
\hline I totally agree with (Name). & \\
\hline I couldn't agree more. & \\
\hline
\end{tabular}

b) Disagreement

\begin{tabular}{|l|l|l|}
\hline Strong & Neutral & $\begin{array}{l}\text { Expressing } \\
\text { Reservations }\end{array}$ \\
\hline $\begin{array}{l}\text { I disagree } \\
\text { completely. }\end{array}$ & I disagree. & Yes, but... \\
\hline $\begin{array}{l}\text { I think you're } \\
\text { wrong. }\end{array}$ & I don't agree. & Maybe, but... \\
\hline $\begin{array}{l}\text { *That's } \\
\text { ridiculous. }\end{array}$ & $\begin{array}{l}\text { I don't see it } \\
\text { quite like that. }\end{array}$ & $\begin{array}{l}\text { I see your } \\
\text { point, but... }\end{array}$ \\
\hline
\end{tabular}

\begin{tabular}{|l|l|l|}
\hline $\begin{array}{l}\text { *Are you } \\
\text { kidding me? }\end{array}$ & $\begin{array}{l}\text { I'm afraid I } \\
\text { disagree }\end{array}$ & $\begin{array}{l}\text { I agree up to } \\
\text { a point, but... }\end{array}$ \\
\hline $\begin{array}{l}\text { *You must be } \\
\text { joking. }\end{array}$ & $\begin{array}{l}\text { That's not how } \\
\text { I see it. }\end{array}$ & $\begin{array}{l}\text { That's a good } \\
\text { idea, but... }\end{array}$ \\
\hline *Get real. & $\begin{array}{l}\text { Sorry, I have to } \\
\text { disagree (with } \\
\text { you). }\end{array}$ & $\begin{array}{l}\text { That's very } \\
\text { interesting, } \\
\text { but... }\end{array}$ \\
\hline & $\begin{array}{l}\text { That would } \\
\text { be great, } \\
\text { except... }\end{array}$ \\
\hline & $\begin{array}{l}\text { I appreciate } \\
\text { your point of } \\
\text { view, but... }\end{array}$ \\
\hline & & Not quite. \\
\hline
\end{tabular}

*Very strong (should be used only if you know the person well)

\section{4) Basic Signposting}

a) Structuring your information:

\begin{tabular}{|c|c|}
\hline $\begin{array}{l}\text { Introducing } \\
\text { the Subject }\end{array}$ & $\begin{array}{l}\text { - Let's start by/with } \\
\text { - First of all, I'II... }\end{array}$ \\
\hline $\begin{array}{l}\text { Finishing one } \\
\text { Subject... }\end{array}$ & $\begin{array}{l}\text { - Well I've told you about... } \\
\text { - That's all I have to say about... } \\
\text { - So much for... }\end{array}$ \\
\hline $\begin{array}{l}\text {...and } \\
\text { Starting } \\
\text { another }\end{array}$ & $\begin{array}{l}\text { - Now, I'II move on to... } \\
\text { - Let me now turn to... } \\
\text { - I'd like now to discuss... } \\
\text { - Let's look now at... }\end{array}$ \\
\hline $\begin{array}{l}\text { Summarizing } \\
\text { and } \\
\text { Concluding }\end{array}$ & $\begin{array}{l}\text { - In conclusion/In closing... } \\
\text { - To sum up what I have just } \\
\text { said... } \\
\text { - To briefly recap what I have } \\
\text { just stated... }\end{array}$ \\
\hline Listing & $\begin{array}{l}\text { - Firstly...Secondly...Lastly... } \\
\text { - First of all...then....next....after } \\
\text { that...finally... } \\
\text { - The first reason is...The second } \\
\text { reason is...The final reason is... } \\
\text { - One exception is... } \\
\text { - There are a few exceptions, of } \\
\text { course. For example...Also... }\end{array}$ \\
\hline
\end{tabular}

\section{5) Logical Flow of an Argument}

a) To begin what you want to say

I would like to begin by...

There are _(number)_points I'd like to make...

I would like to make a few comments/remarks about...

b) To change to a new point

I would now like to turn to...

The next issue I'd like to focus on is...

Turning to... 
c) To add another point

Furthermore/Moreover...

I also want to add...

Not only...but also...

d) To give an example

Let me give an example

A case in point is...

For example...

To illustrate this point...

e) To stress a point

I'd like to point out...

I would have you know...

f) To contrast 2 points

On the one hand...but on the other hand...

Although (A states this, B states that)

Where as (A states this, B states that)

g) To make a generalization

On the whole...

In general...

Generally speaking

By and large...

Broadly speaking...

All in all...

All things considered...

h) To state a preference

I would rather...than...

I would prefer to...

I tend to favor....as opposed to...

...has an advantage over...in that...

i) To finish what you want to say

Let me conclude by saying...

I'd like to conclude by stating that...

Allow me to conclude by highlighting that...

j) Grabbing attention by drawing information from your own knowledge and experiences

Here's a little known fact..

It's hard to believe, but...

When I think about...

Have you ever wondered why...?

\section{6) Active Listening}

a) Making a personal comment based on what another person says

Acknowledging Reacting

-I see. - That's (interesting/too bad).

- Got it. - How (nice/lovely/awful)!

- That's clear.

- What a

- I understand (surprise/coincidence/shock)
- Now I see what $\cdot$ Oh really?

you mean $\quad$ Oh (no/dear)!

b) When you don't have much to say

Pausing

No comment

-Uhm...

- I'm sorry I have nothing

- Ah...

to add right now.

- Well...

- There is nothing I can

- Let me think... think of right now.

\section{7) Supporting an argument with Numbers and Trends}

- The vertical axis shows...The horizontal axis shows...

- This (table, pie chart/graph/diagram)

(gives/shows/summarizes)...

- If you look at the graph...

- Could I draw your attention to the chart?

- As you can see..

- Notice that...

- The important thing here is..

\section{8) Infinitive verbs and Adverbs to Explain Graphs}

\begin{tabular}{l|l|}
\hline Infinitive Verbs & Adverbs \\
\hline - To increase & - Quickly \\
- To rise & - Sharply \\
- To grow & - Significantly \\
- To jump & - Dramatically \\
- To skyrocket & - Steadily \\
- To fall & - Gradually \\
- To decrease & - Slightly \\
- To decline & - Slowly \\
- To drop & \\
- To stay the same & \\
- To be above/below & \\
- To reach a peak & \\
- To hit a low & \\
- To drop back & \\
- To recover & \\
- To stand at & \\
- To remain high & \\
- To fluctuate & \\
- To level off & \\
- & \\
nstructor created handouts for: “Advanced English \\
Contemporary Issues in Japanese Society)"-2016
\end{tabular}

\section{Appendix 2.}

5 Keys to Effective Communications within a Group

\begin{tabular}{|l|l|l|}
\hline 5 Keys & Why & Description \\
\hline Confidence & $\begin{array}{l}\text { - Confidence } \\
\text { gives you } \\
\text { credibility to }\end{array}$ & $\begin{array}{l}\text { Maintain eye- } \\
\text { contact. }\end{array}$ \\
\hline
\end{tabular}




\begin{tabular}{|c|c|c|}
\hline & $\begin{array}{l}\text { your } \\
\text { statements. }\end{array}$ & $\begin{array}{l}\text { - Use a strong } \\
\text { voice and } \\
\text { articulate. }\end{array}$ \\
\hline Assertive & $\begin{array}{l}\text { - Your positions } \\
\text { (ideas) should } \\
\text { be clarified } \\
\text { from the start. } \\
\text { - Assertiveness } \\
\text { enhances } \\
\text { credibility. }\end{array}$ & $\begin{array}{l}\text { Agree or } \\
\text { disagree } \\
\text { clearly and } \\
\text { promptly. } \\
\text { Interact } \\
\text { assertively } \\
\text { and do not } \\
\text { hesitate to } \\
\text { express your } \\
\text { opinions. Do } \\
\text { not give up } \\
\text { easily when } \\
\text { challenged. }\end{array}$ \\
\hline Initiative & $\begin{array}{l}\text { - Active } \\
\text { listening } \\
\text { ensures } \\
\text { understanding. } \\
\text { - You are here to } \\
\text { contribute- } \\
\text { make your } \\
\text { presence } \\
\text { worthwhile. }\end{array}$ & $\begin{array}{l}\text { Give signals } \\
\text { to show you } \\
\text { are listening } \\
\text { and are } \\
\text { interested. } \\
\text { - Interrupt } \\
\text { without } \\
\text { hesitation to } \\
\text { clarify or to } \\
\text { confirm. } \\
\text { - Assume an } \\
\text { active role in } \\
\text { discussions. }\end{array}$ \\
\hline Logic & $\begin{array}{l}\text { - Ideas should be } \\
\text { presented } \\
\text { logically and } \\
\text { concisely. } \\
\text { - Relevant } \\
\text { information } \\
\text { that your } \\
\text { audience } \\
\text { would } \\
\text { understand. }\end{array}$ & $\begin{array}{l}\text { - State your } \\
\text { main idea } \\
\text { first, then } \\
\text { support it with } \\
\text { concise } \\
\text { information, } \\
\text { data and } \\
\text { examples } \\
\text { etc... } \\
\text { - Use proper } \\
\text { signposting } \\
\text { and phrases as } \\
\text { it relates to } \\
\text { the logical } \\
\text { flow of an } \\
\text { argument. } \\
\text { - Consider what } \\
\text { your audience } \\
\text { knows. }\end{array}$ \\
\hline $\begin{array}{l}\text { Open- } \\
\text { mindedness }\end{array}$ & $\begin{array}{l}\text { - Respect } \\
\text { different } \\
\text { viewpoints. }\end{array}$ & $\begin{array}{l}\text { - Encourage } \\
\text { others to } \\
\text { express their } \\
\text { opinions. } \\
\text { - Paraphrase } \\
\text { others to } \\
\text { ensure } \\
\text { understanding }\end{array}$ \\
\hline
\end{tabular}

